\title{
Syphilis in Pregnancy and Congenital Syphilis: Reality in a Portuguese Central University Hospital
}

\section{Sífilis na gravidez e sífilis congênita: realidade de um hospital universitário central português}

\author{
Magda Magalhães ${ }^{1}$ Lígia Basto ${ }^{2}$ Ana Luísa Arei \\ Maria Eulália Afonso ${ }^{2}$ Paulo Moura1,3 \\ ${ }^{1}$ Obstetric Unit, Centro Hospitalar e Universitário de Coimbra, \\ Coimbra, Portugal \\ 2 Pediatric Unit, Centro Hospitalar e Universitário de Coimbra, \\ Coimbra, Portugal \\ ${ }^{3}$ Vice-Dean of Medicine Faculty, Universidade de Coimbra, \\ Coimbra, Portugal
}

\author{
Sofia Franco ${ }^{1}$ Maria Eugénia Malheiro ${ }^{1}$
}

Rev Bras Ginecol Obstet 2017;39:265-272.

\begin{abstract}
Address for correspondence Magda Maria do Vale Pinto Lopes de Magalhães, MD, Rua Luís Castro Rodrigues da Silva, lote 11, 4C. 3030254 Pinhal de Marrocos, Coimbra, Portugal (e-mail: magdamariamagalhaes@gmail.com).
\end{abstract}

\begin{abstract}
Purpose To evaluate maternal-fetal surveillance and follow-up of infants at risk for congenital syphilis (CS).

Methods Retrospective cohort study in a Portuguese Tertiary Referral Hospital. The main inclusion criterion was a positive syphilis serology. The study included all pregnant women that delivered in our hospital between January 2004 and December 2013. The neonates were classified according to their probability of infection based on the Centers for Disease Control and Prevention guidelines.

Results Among the 27 pregnancies at risk for CS, $48.2 \%(n=13)$ of the women had a diagnosis during the 1 st trimester, and the median gestational age at the end of the treatment was 28 weeks. Inadequate treatment was noted in $44.4 \%(n=12)$ of the women. Adverse pregnancy outcomes were observed in $30.8 \%$ of the cases $(n=8), 5$ of which had been adequately treated. We found $2(7.7 \%)$ cases with "proven or highly probable CS," 10 (38.5\%) with "possible CS," 12 (46.1\%) with "less likely CS," and 2 (7.7\%) with "unlikely CS." Among the infants, the treatment was successful, except for 1 neurosyphilis case.

Keywords

- syphilis

- infection

- congenital syphilis

- prenatal diagnosis

Conclusion This study highlights many of the difficulties/concerns encountered in the maternal-neonatal management of syphilis. We highlight the importance of assuring the early detection of the infection as a way of guaranteeing the timely treatment, as well as a good compliance to the treatment and follow-up through a more efficient pregnant women surveillance network.
\end{abstract}

received

January 7, 2017

accepted

March 14, 2017

published online

June 13, 2017
Copyright (e 2017 by Thieme Revinter

Publicações Ltda, Rio de Janeiro, Brazil
License terms

(c) $(1) \$$ 10.1055/s-0037-1603646. ISSN 0100-7203. 


\section{Resumo}

\section{Palavras-chave}

- sífilis

- infecção

- sífilis congênita

- diagnóstico pré-natal
Objetivo Avaliar a vigilância materno-fetal e o acompanhamento de crianças em risco de sífilis congênita (SC).

Métodos Estudo de coorte retrospetivo desenvolvido num hospital terciário de referência, cujo principal critério de inclusão foi a presença de serologia positiva para sífilis. O estudo incluiu todas as grávidas admitidas no nosso Hospital entre janeiro de 2004 e dezembro de 2013. Os recém-nascidos foram classificados de acordo com a probabilidade de infeção, com base nas recomendações do Centers for Disease Control and Prevention.

Resultados Entre as 27 gravidezes em risco de SC, 48,2\% $(n=13)$ tiveram diagnóstico durante $\mathrm{o} 1^{\circ}$ trimestre; a idade gestacional média no final do tratamento foi de 28 semanas. Em 44,4\% $(n=12)$ das mulheres, o tratamento foi considerado inadequado. Em $30,8 \%$ dos casos $(n=8)$ houve algum evento adverso da gravidez, dos quais 5 foram adequadamente tratados. Em dois dos casos $(7,7 \%)$ a SC foi provada ou considerada como altamente provável, 10 (38,5\%) com SC provável, $12(46,1 \%)$ com SC pouco provável, e 2 (7,7\%) com SC improvável. Nos lactentes, o tratamento foi bem sucedido, com exceção de um caso de neurossífilis.

Conclusão Este estudo visa realçar muitas das dificuldades/preocupações encontradas na vigilância materno-neonatal dos casos com diagnóstico de sífilis. ublinhamos, não só, a importância de se assegurar a deteção precoce de infeção como forma de se garantir o tratamento atempado, mas também, uma adequada adesão à vigilância/ tratamento, através de uma rede mais eficiente entre as diferentes instituições envolvidas no acompanhamento das grávidas.

\section{Introduction}

Syphilis is a sexually transmitted infection caused by Treponema pallidum (Tp) that progresses through active and latent stages with different clinical presentations. Although fewer than $10 \%$ of syphilis cases are reported in developed countries, ${ }^{1}$ several epidemiologic studies have shown an increase in early syphilis over the last decade. The annual report of the European Centre for Disease Prevention and Control (ECDC) found that the number of early-stage syphilis cases in Portugal increased by more than $50 \%$ between 2008 and $2012 .^{2}$ Accordingly, congenital syphilis (CS) has also reemerged despite systematic screening during pregnancy. Although the numbers were small, the ECDC reported the second highest incidence of CS in Europe (12.1/100,000 inhabitants) in Portugal. ${ }^{3}$

Adverse pregnancy outcomes of syphilis may occur in $66.5 \%$ of pregnant women with untreated syphilis, and include late spontaneous abortion, prematurity, small for gestational age (SGA) neonates, and stillbirth. ${ }^{4}$ Thus, CS can manifest, according to the severity, as neonatal death, neonatal disease, or latent infection leading to later sequelae. Unfortunately, delivery at term of live infants who are fully asymptomatic may occur in approximately two-thirds of live born cases with untreated or inappropriately treated mothers. The early detection and adequate treatment of syphilis in pregnancy are the key points of this preventable condition. ${ }^{5}$

The aim of our study was to evaluate the maternal surveillance of syphilis and its clinical approach, the treatment and the follow-up of infants at risk for CS according to the most recent guidelines from the Centers for Disease Control and Prevention (CDC). ${ }^{6}$

\section{Methods}

This retrospective cohort study from a Portuguese Tertiary Referral Hospital is the result of a study of all cases with the International Classification of Diseases, Ninth Revision (ICD9), codes of "maternal syphilis complicating pregnancy" and "congenital syphilis" over a period of 10 years. The maternal and infant medical records were thoroughly reviewed by the main researcher using maternal and pediatrics computer databases and paper clinical files.

The main inclusion criteria were positive non-treponemal tests (NTTs) and treponemal tests (TTs) among all pregnant women that had delivered at our hospital between January 2004 and December 2013.

The adverse pregnancy outcomes were defined as prematurity, SGA neonates $(<\mathrm{p} 10)$, perinatal death, or symptomatic CS in the newborn. Inadequate treatment in pregnancy was defined as untreated syphilis, undocumented therapy, the use of antibiotics other than benzathine penicillin, insufficient dose regimen, and inadequate serologic response to treatment (less than 4 -fold decrease in NTT titers by 3 months) or therapy not taken until 1 month before delivery.

In Portugal, routine screening for syphilis is mandatory during the first and third trimesters of pregnancy. ${ }^{7}$ This screening includes a quantitative NTT Venereal Disease Research Laboratory (VDRL) or Rapid Plasma Reagin (RPR) and a TT - Treponema pallidum Particle Agglutination Assay (TP-PAA), Fluorescent Treponemal Antibody absorption (FTAabs) or chemiluminescence assay (CLIA). ${ }^{7}$ Non-treponemal tests are usually used for screening and monitoring therapy, while TTs are used to confirm the diagnosis. 
The staging of maternal syphilis is complex; it is based on the combination of history, physical examination, epidemiologic features and serologic tests. ${ }^{8}$ The quantitative maternal non-treponemal titer, especially if $>1: 8$, might be a marker of early infection and bacteremia. However, the risk for fetal infection is still significant in pregnant women with late latent syphilis and low titers. Latent syphilis is defined as having serologic proof of infection without the symptoms of the disease, while late latent syphilis is considered when the infection occurred more than 12 months before. ${ }^{6}$

All neonates whose mothers had a reactive NTT and TT were clinically examined and evaluated with serologic tests from peripheral blood. Maternal history of Tp infection and treatment for syphilis were considered when evaluating and treating the neonate for CS, except when the diagnosis of CS was proven or highly probable. In this context, we decided to classify our cases according to their probability of infection based on the 4 scenarios proposed by the CDC guidelines (1 proven or highly probable CS; 2 - possible CS; 3 - less likely CS; 4 - unlikely CS). ${ }^{6}$

Intramuscular (IM) benzathine penicillin $\mathrm{G}$ regimens were used in the mothers' treatment according to the stage of infection (2.4 to 4.8 million units for early stage syphilis, and 7.2 million units in total, administered as 3 doses of 2.4 million units over 3 weeks, for latent syphilis or syphilis of unknown duration). For the neonates, the main regimens were IM benzathine penicillin $\mathrm{G}(50,000$ units $/ \mathrm{Kg})$ in a single dose, or parenteral aqueous crystalline penicillin $\mathrm{G}(100,000-150,000$ units $/ \mathrm{Kg} /$ day) for a total of 10 to 14 days, according to their probability of infection.

The clinical and serologic follow-up of the seropositive infants was performed, including NTTs every 2-3 months, until there was a nonreactive result or a 4 -fold decrease in antibody titers. In an uninfected or successfully treated infant, NTT titers are usually nonreactive by 6 months of age. Passively acquired syphilis antibodies may be present for longer, up to around 15 months of age. ${ }^{9}$

\section{Results}

\section{Obstetric Surveillance}

According to the selection criteria, between 2004 and 2013 we had 27 women with positive syphilis serologic results (-Table 1). The number of cases reported each year was similar between 2005 and 2010. However, between 2011 and 2013 we noticed an increase in the reported incidence, with $55.5 \%$ (15/27) of the cases occurring during this period of time. The median maternal age at delivery was 32 years (18-43); most patients were Caucasian (89\%) and had poor education; 2 of them were co-infected with HIV. Out of the 9 cases without a proper pregnancy follow-up, 7 had irregular antenatal care, and 2 had no surveillance at all.

Among those 27 pregnancies at risk for CS, 7 of them had a previously known diagnosis of syphilis (5 with well-documented prior treatments). A total of $48.2 \%(13 / 27)$ had a positive diagnosis during the 1st trimester, 33.3\% (9/27), at the 2 nd trimester, $11.1 \%$ (3/27), at the 3rd trimester, and $7.4 \%$ $(2 / 27)$, at delivery. All cases were classified as latent syphilis
Table 1 Maternal and obstetric characteristics; evaluation, management and prevention of CS

\begin{tabular}{|c|c|}
\hline Age at delivery $(y)($ mean $\pm 2 \sigma)$ & $\begin{array}{l}32.5 \pm 5.7 \\
(18-43)\end{array}$ \\
\hline $\begin{array}{l}\text { Number of previous gestations } \\
\text { (median; range) }\end{array}$ & $2(0-8)$ \\
\hline Parity (median; range) & $1(0-6)$ \\
\hline Immigrant mothers & $3 / 27(11.1)$ \\
\hline Unemployed & $9 / 27(33.3)$ \\
\hline Inadequate pregnancy follow-up & $12 / 27(44.4)$ \\
\hline Median RPR titers at treatment & $1: 16$ \\
\hline $\begin{array}{l}\text { Weeks of gestation at the end of the } \\
\text { treatment (mean } \pm 2 \sigma)^{i}\end{array}$ & $27.9 \pm 6.9$ \\
\hline Adequate antenatal treatment ${ }^{\mathrm{ii}}$ & $15 / 27(55.6)$ \\
\hline Median RPR titers at delivery & $1: 4$ \\
\hline $\begin{array}{l}\text { Gestational age at delivery } \\
(\text { mean } \pm 2 \sigma)\end{array}$ & $\begin{array}{l}38.0 \pm 1.9 \\
(33-41)\end{array}$ \\
\hline Preterm delivery $(<37 \mathrm{WG})^{\mathrm{iii}}$ & $5 / 26(19.2)$ \\
\hline $\begin{array}{l}\text { Birth weight }(g) \\
\text { (mean } \pm 2 \sigma)\end{array}$ & $\begin{array}{l}3087 \pm 699 \\
(1830-4700)\end{array}$ \\
\hline Small for gestational age $(<\mathrm{p} 10)$ & $5 / 26(19.2)$ \\
\hline Median RPR titer of neonate & $1: 4$ \\
\hline
\end{tabular}

'Excluding 12 women untreated or incorrectly treated, and 2 women with adequate treatment before pregnancy with stable NTT titers. ii Including 2 women with adequate treatment before pregnancy with stable NTT titers.

iiiExcluding one woman with spontaneous abortion at $1^{\text {st }}$ trimester Abbreviations: CS, congential syphilis; RPR, rapid plasma reagin.

(5 early latent [18.5\%], 7 late latent [25.9\%], and 15 latent syphilis [55.6\%] of unknown duration at the time of the diagnosis). One pregnancy resulted in a spontaneous abortion at 12 weeks, without fetal findings consistent with CS.

Inadequate treatment was observed in 12 women (44.4\%): 7 of them with the recommended treatment, but less than 4 weeks before delivery ( 3 needed a second bout of treatment due to insufficient serologic response), 4 had no treatment during pregnancy, and 1 was treated with erythromycin. Among the 15 women who were properly treated, only 8 had a well-documented treatment of their partners. Intramuscular benzathine penicillin $G$ regimens were used in all cases, according to the stage of infection. None of our cases had prenatal ultrasonography findings suggestive of CS.

\section{Neonatal Outcomes}

The NTTs and TTs were positive in 26 newborns (- Table $\mathbf{1}$ ). The mean birth weight was $3,087 \mathrm{~g}$, and 5 of them were SGA (19.2\%). Twenty neonates were delivered at term, and 5 were late preterm (19.2\%). No multiple births were reported.

Overall, adverse outcomes were observed in $30.8 \%$ of cases (8/26) (-Table 2), 5 of which had been adequately treated and had no other obstetric comorbidities. The main events were 2 cases of CS and 6 cases of preterm delivery and/or SGA neonates. Considering those 5 well-treated cases, the median gestational age at the end of the treatment was 28 weeks of 
268 Syphilis in Pregnancy and Congenital Syphilis Magalhães et al.

Table 2 Cases with adverse pregnancy outcomes: pregnancy follow-up and neonatal outcomes

\begin{tabular}{|c|c|c|c|c|c|}
\hline \multirow[t]{2}{*}{ Cases } & \multicolumn{5}{|c|}{ Pregnancy follow-up } \\
\hline & $\begin{array}{l}\text { Maternal age/ } \\
\text { Gravida/Para }\end{array}$ & $\begin{array}{l}\text { Stage of disease/ } \\
\text { Time of diagnosis }\end{array}$ & Neonatal outcomes & \multicolumn{2}{|c|}{ Maternal treatment } \\
\hline 1 (SGA + PTD) & $\begin{array}{l}27 \text { years } \\
\text { Primigravida }\end{array}$ & $\begin{array}{l}\text { Early latent } \\
\text { 2nd trimester }\end{array}$ & Adequate & \multicolumn{2}{|c|}{$\begin{array}{l}\text { Incorrectly treated } \\
\text { (Incomplete } 2 \text { nd treatment at } 31 \text { WG - inadequate serologic } \\
\text { response) }\end{array}$} \\
\hline $2(\mathrm{SGA})$ & $\begin{array}{l}36 \text { years } \\
\text { Gravida } 2 / \text { Para } 1\end{array}$ & $\begin{array}{l}\text { Early latent } \\
\text { 2nd trimester }\end{array}$ & Adequate & \multicolumn{2}{|l|}{ Properly treated ${ }^{c}$} \\
\hline 3 (PTD) & $\begin{array}{l}32 \text { years } \\
\text { Primigravida }\end{array}$ & $\begin{array}{l}\text { Early latent } \\
\text { 2nd trimester }\end{array}$ & Adequate & \multicolumn{2}{|l|}{ Properly treated ${ }^{\mathrm{C}}$} \\
\hline $4(\mathrm{SGA})$ & $\begin{array}{l}19 \text { years } \\
\text { Primigravida }\end{array}$ & $\begin{array}{l}\text { Latent of unknown } \\
\text { duration/1st trimester }\end{array}$ & Adequate & \multicolumn{2}{|c|}{$\begin{array}{l}\text { Properly treated } \\
\text { (2nd treatment at } 28 \text { WG - inadequate serologic response) }\end{array}$} \\
\hline $5(\mathrm{CS})$ & $\begin{array}{l}29 \text { years } \\
\text { Gravida } 3 / \text { Para } 2\end{array}$ & $\begin{array}{l}\text { Latent of unknown } \\
\text { duration } / 2^{\circ} \text { trimester }\end{array}$ & $\begin{array}{l}\text { Irregular } \\
\text { Surveillance }\end{array}$ & \multicolumn{2}{|l|}{ Properly treated ${ }^{\mathrm{a}}$} \\
\hline $6(\mathrm{CS})$ & $\begin{array}{l}19 \text { years } \\
\text { Primigravida }\end{array}$ & $\begin{array}{l}\text { Latent of unknown } \\
\text { duration/ At delivery }\end{array}$ & Without surveillance & \multicolumn{2}{|l|}{ Not treated } \\
\hline 7 (PTD) & $\begin{array}{l}29 \text { years } \\
\text { Gravida 4/Para } 2\end{array}$ & $\begin{array}{l}\text { Late latent } \\
\text { (Previously treated) }\end{array}$ & $\begin{array}{l}\text { Irregular } \\
\text { Surveillance }\end{array}$ & \multicolumn{2}{|l|}{ Properly treated ${ }^{a}$} \\
\hline $8(\mathrm{SGA}+\mathrm{PTD})$ & $\begin{array}{l}38 \text { years } \\
\text { Gravida 8/ Para } 6\end{array}$ & $\begin{array}{l}\text { Late latent } \\
\text { (Not treated) }\end{array}$ & $\begin{array}{l}\text { Irregular } \\
\text { Surveillance }\end{array}$ & \multicolumn{2}{|l|}{ Incorrectly treated } \\
\hline \multirow[t]{2}{*}{ Cases } & \multicolumn{5}{|c|}{ Pregnancy follow-up } \\
\hline & $\begin{array}{l}\text { Other obstetric } \\
\text { complications }\end{array}$ & $\begin{array}{l}\text { Time at deliveryl } \\
\text { Birth weight }\end{array}$ & $\begin{array}{l}\text { RPR Titers } \\
\text { (Newborn/ mother) }\end{array}$ & $\begin{array}{l}\text { Probability of } \\
\text { Developed } \mathrm{CS}^{\mathrm{b}}\end{array}$ & CS \\
\hline 1 (SGA + PTD) & None & $\begin{array}{l}36 \mathrm{WG} \\
2,030 \mathrm{~g}(\mathrm{p} 1)\end{array}$ & $1: 16 / 1: 16$ & Possible & $\begin{array}{l}\text { No } \\
\text { Aqueous penicillin } G \\
10 \text { days }(100,000-150,000 \text { units/Kg/day })\end{array}$ \\
\hline $2(\mathrm{SGA})$ & None & $\begin{array}{l}39 \mathrm{WG} \\
2,660 \mathrm{~g}(\mathrm{p} 4)\end{array}$ & 1:16/ 1:16 & Less likely & No \\
\hline 3 (PTD) & Thrombophilia & $\begin{array}{l}33 \mathrm{WG} \\
2,130 \mathrm{~g}(\mathrm{p} 48)\end{array}$ & $1: 32 / 1: 32$ & Less likely & $\begin{array}{l}\text { No } \\
\text { Aqueous penicillin } G \\
10 \text { days }(100,000-150,000 \text { units } / \mathrm{Kg} / \text { day })^{d}\end{array}$ \\
\hline $4(\mathrm{SGA})$ & None & $\begin{array}{l}38 \mathrm{WG} \\
2,260 \mathrm{~g}(\mathrm{p} 1)\end{array}$ & $1: 4 / 1: 4$ & Less likely & No \\
\hline $5(\mathrm{CS})$ & None & $\begin{array}{l}40 \text { WG } \\
3,950 \mathrm{~g}(\mathrm{p} 85)\end{array}$ & $1: 0 / 1: 0$ & $\begin{array}{l}\text { Proven or highly } \\
\text { probable }\end{array}$ & $\begin{array}{l}\text { Yes } \\
\text { Aqueous penicillin } G \\
10 \text { days }(100,000-150,000 \text { units/ } \mathrm{Kg} / \text { day })\end{array}$ \\
\hline $6(\mathrm{CS})$ & None & $\begin{array}{l}36 \mathrm{WG} \\
2,215 \mathrm{~g}(\mathrm{p} 4)\end{array}$ & $1: 16 / 1: 16$ & $\begin{array}{l}\text { Proven or highly } \\
\text { probable }\end{array}$ & $\begin{array}{l}\text { Yes } \\
\text { Aqueous penicillin } G \\
14 \text { days }(100,000-150,000 \text { units/Kg/day })\end{array}$ \\
\hline 7 (PTD) & None & $\begin{array}{l}34 \mathrm{WG} \\
2,220 \mathrm{~g}(\mathrm{p} 32)\end{array}$ & $1: 4 / 1: 8$ & Less likely & No \\
\hline 8 (SGA + PTD) & None & $\begin{array}{l}35 \mathrm{WG} \\
1830 \mathrm{~g}(\mathrm{p} 1)\end{array}$ & $1: 4 / 1: 4$ & Possible & $\begin{array}{l}\text { No } \\
\text { Aqueous penicillin } G 10 \text { days }(100,000- \\
150,000 \text { units/Kg/day) }\end{array}$ \\
\hline
\end{tabular}

Abbreviations: CS, congenital syphilis; p, percentile; PTD, preterm delivery; RPR, rapid plasma reagin; SGA, small for gestational age; WG, weeks of gestation.

Notes: ${ }^{\text {a }}$ Three doses of intramuscular benzathine penicillin G - 7.2 million IU.

bProbability of developed CS based on the four scenarios proposed by the CDC guidelines.

${ }^{\mathrm{C}}$ Two doses of intramuscular benzathine penicillin $\mathrm{G}-4.8$ million IU

${ }^{\mathrm{d}}$ Treatment at 5 months after an elevation in the CLIA titers 
gestation (WG); 2 were classified as early latent syphilis, 2 as latent of unknown duration, and 1 as late latent previously treated. Thus, $\sim 60 \%$ (3/5) of the pregnancies with early latent syphilis, $28.6 \%$ (2/7) of the ones with late latent syphilis, and $20 \%(3 / 15)$ of the pregnancies with latent syphilis of unknown duration resulted in adverse fetal events.

Among the 18 remaining neonates, 2 were secondarily admitted before 6 months of age after an elevation in the TT titers, with a subsequent adequate treatment response.

According to the probability of developing CS based on the 4 scenarios proposed by the CDC guidelines, we found 2 cases of "proven or highly probable CS" (7.7\%) (CDC scenario 1, - Table 3), both with an abnormal physical examination consistent with CS, and both reported in 2011. In one case, the parents were properly treated in the 3rd trimester, and had a later, but weakly positive, RPR titer (1:1). The neonatal syphilis serology was compatible with the placental transfer of maternal antibodies; however, hypotonia, seizures and transfontanellar ultrasound findings suggested neurosyphilis. In the other case, the diagnosis was at the delivery, with an RPR titer of 1:16. Although the newborn had the same NTT titer as the mother, he presented signs of CS (anemia and thrombocytopenia, hepatosplenomegaly, rash, neurologic signs and radiographic signs of CS in the long bones).

From the 10 neonates with "possible CS" (38.5\%) (CDC scenario 2), their mothers were not treated or underwent improper treatments, with serum quantitative NTT titers less than or equal to 4-fold the maternal titer. The mean birth weight was 3,236 $\mathrm{g} \pm 848 \mathrm{~g}$, and the mean gestational age at birth was $38.3 \mathrm{WG} \pm 2.0 \mathrm{WG}$, with 2 preterm deliveries (20.0\%). All neonatal RPR serum titers were $\leq 1: 16$, and 2 of them were nonreactive.

Among the 12 neonates with "less likely CS" (46.1\%) (CDC scenario 3) whose mothers were properly treated during pregnancy, the mean birth weight was $2,886 \mathrm{~g} \pm 491 \mathrm{~g}$, and the mean gestational age at birth was 37.6 WG $\pm 2.1 \mathrm{WG}$, with 2 preterm deliveries (16.7\%).

There were 2 neonates with "unlikely CS" (7.7\%) (CDC scenario 4) whose mothers' treatment was adequate before pregnancy, and their NTT titers remained low and stable before and during pregnancy. Both were born at term, and had an RPR $<1: 4$.

Table 3 Description of two cases with proven CS

\begin{tabular}{|c|c|c|}
\hline Case & 1 & 2 \\
\hline $\begin{array}{l}\text { Maternal age/ } \\
\text { Gravida/Para }\end{array}$ & $\begin{array}{l}19 \text { years } \\
\text { Primigravida }\end{array}$ & $\begin{array}{l}29 \text { years } \\
\text { Gravida3 / Para2 }\end{array}$ \\
\hline \multicolumn{3}{|l|}{ Pregnancy follow-up } \\
\hline $\begin{array}{l}\text { Time at diagnoses/ } \\
\text { Stage of disease }\end{array}$ & $\begin{array}{l}\text { At delivery/ } \\
\text { Latent of unknown duration }\end{array}$ & $\begin{array}{l}28 \mathrm{WG} / \\
\text { Latent of unknown duration }\end{array}$ \\
\hline Follow-up & None & Irregular \\
\hline Maternal treatment & None & $\begin{array}{l}\text { Properly treated: } 3 \text { doses of } \\
\text { intramuscular penicillin } G \\
(7.2 \text { million } \mathrm{IU})^{i}\end{array}$ \\
\hline $\begin{array}{l}\text { Time at delivery/ Type of birth/ Birth } \\
\text { weight/ sex/ Apgar score }\end{array}$ & 36 WG; Eutocic; $2,115 \mathrm{~g}$ (p4); Male; 5/7 & $\begin{array}{l}40 \text { WG; Vacuum-assisted; 3,950 g (p85); } \\
\text { Male; 5/8 }\end{array}$ \\
\hline \multicolumn{3}{|l|}{ Neonatal outcomes and evaluation } \\
\hline Clinical signs & $\begin{array}{l}\text { Maculopapular rash; } \\
\text { hepatosplenomegaly jaundice; upper } \\
\text { gastrointestinal bleeding; seizures }\end{array}$ & $\begin{array}{l}\text { Respiratory distress; } \\
\text { hypotonia; seizures }\end{array}$ \\
\hline $\begin{array}{l}\text { RPR Titers } \\
\text { (Newborn/ mother) }\end{array}$ & $1: 16 / 1: 16^{\mathrm{ii}}$ & $\begin{array}{l}\text { 1:0/1:0 } \\
T p P C R+(C S F)^{i i i}\end{array}$ \\
\hline Analytic findings & $\begin{array}{l}\text { Anemia and thrombocytopenia; } \\
\text { hyperglycemia; hyperbilirubinemia }\end{array}$ & Anemia and thrombocytopenia \\
\hline Imaging findings & $\begin{array}{l}\text { Transfontanellar ultrasound: } \\
\text { bilateral intraventricular hemorrhage; } \\
\text { hyperechogenic corpus callosum } \\
\text { Long-bone X-ray: periostitis }\end{array}$ & $\begin{array}{l}\text { Transfontanellar ultrasound: } \\
\text { abnormalities on the ventricular lining } \\
\text { and bilateral intraventricular strand, } \\
\text { mild ventricular dilatation, and bilateral } \\
\text { hypoechogenic area in the choroid } \\
\text { plexus. } \\
\text { MRI: subdural hemorrhage }\end{array}$ \\
\hline Treatment & $\begin{array}{l}\text { Aqueous penicillin G } 14 \text { days } \\
(100,000-150,000 \text { units } / \mathrm{Kg} / \text { day })\end{array}$ & $\begin{array}{l}\text { Aqueous penicillin G } 10 \text { days } \\
(100,000-150,000 \text { units } / \mathrm{Kg} / \text { day })\end{array}$ \\
\hline
\end{tabular}

'Partner was properly treated too.

iiLumbar puncture was not performed because the diagnosis of a grade I intraventricular hemorrhage contra-indicated the procedure.

iiiBlood Tp PCR (mother and newborn) negative; CLF: Cerebrospinal fluid.

Abbreviations: CS, congenital syphilis; CSF, cerebrospinal fluid; MRI, magnetic resonance, imaging; PCR polymerase chain reaction; RPR, rapid

plasma reagin; SGA, small for gestational age; Tp, Treponema pallidum; WG, weeks of gestation. 


\section{Neonatal Evaluation, Treatment and Follow-Up}

Lumbar puncture was not performed in 1 of the 2 cases of "proven CS" (-Table 3), since the diagnosis of a grade I intraventricular hemorrhage contra-indicated the procedure. In the other case (suspicion of neurosyphilis), the cerebrospinal fluid (CSF) was analyzed using a real-time probe-based polymerase chain reaction (PCR) method, with a positive result. Nevertheless, in the 2 cases, Tp was not detected in the blood samples from either the mother or the newborn. Both were treated with intravenous aqueous crystalline penicillin $\mathrm{G}$ for 10 to 14 days. At follow-up, the RPR titers declined and were nonreactive between 6 and 2 months after birth respectively. At 6 months, a PCR of the CSF of the infant with proven neurosyphilis was performed, with a negative result. At 12 months, this child had a global developmental delay with a Griffiths developmental quotient of less than $85 \%$ and spastic diplegic cerebral palsy.

Among the 10 neonates with "possible CS", 1 underwent a lumbar puncture at 2 months of age after an elevation in the TP-PA titer, and 7 underwent long-bone radiographs. A complete blood count $(\mathrm{CBC})$ was obtained for all children. The 2 neonates with nonreactive RPRs and normal clinic evaluations did not receive any treatment; 3 received a single dose of IM benzathine penicillin $G$, and in 5 , aqueous crystalline penicillin $\mathrm{G}$ was administered for 10 days. Eight children continued with follow-up appointments, and RPR seroreversion was verified in all cases between 2 and 9 months.

Among the 12 infants with "less likely CS", only one was treated with parenteral aqueous crystalline penicillin $G$ for 10 days due to an RPR titer of $1: 8,4$-fold higher than the mothers' titer (1:2). The RPR became nonreactive at 12 months of age. All infants had adequate follow-ups, and their RPRs were nonreactive before 4 months of age. In one of these infants, a lumbar puncture was performed at 5 months, after an elevation in the CLIA titer. The result was negative, with a normal $\mathrm{CBC}$ and a normal long-bone radiograph. At that time, a 10-day course of aqueous crystalline penicillin $G$ was administered with a successful outcome. Finally, of the 2 neonates with "unlikely CS," 1 received a single dose of IM benzathine penicillin (RPR 1:4), while the other did not receive any treatment at all (nonreactive RPR).

\section{Discussion}

Syphilis infection during pregnancy still represents a worldwide public health problem, with rates of CS rising in several parts of the world. ${ }^{10}$ The annual report of the ECDC showed an increased number of early syphilis cases in Portugal of more than 50\% between 2008 and 2012; ${ }^{2}$ accordingly, a high rate of congenital syphilis was also reported. Our data reflect this reality, showing that $55.5 \%$ of neonates with positive syphilis serology were born between 2011 and 2013, with 2 cases of proven CS born in 2011. The highest seroprevalence in pregnant women was found in 2012 , of $0.19 \%$, and the lowest one in 2006, of $0.03 \%$.

Effective prevention and identification of CS depends primarily on the identification of syphilis in pregnant women and, therefore, on the routine screening of all pregnant women for syphilis. With the re-emergence of syphilis in Portugal, universal screening of all pregnant women continues to be important, and remains the standard of care. Concerns about the cost-effectiveness of this screening in low-prevalence settings have been repeatedly proven. ${ }^{11,12}$

The infected women in our cohort were young (median age of 32 years old); 2 of them were co-infected with HIV, and apparently without high-risk behavior patterns; the rate of immigrant mothers was low (11.1\%). These findings reinforce the importance of antenatal screening for syphilis even in developed countries.

Congenital syphilis is theoretically eradicable through antenatal care screening programs that assure the early identification and prompt treatment of women with a positive serology, ideally by the 24 th WG. ${ }^{3,13}$ However, coverage of the 1 st trimester screening and timely antenatal treatment are still a problem.

In our study, $48.2 \%$ of the women were diagnosed during the 1st trimester, and the mean WG at the end of the treatment was 28 weeks among the well-treated women. Forty-four percent were women treated incorrectly, and the main cause seems to be maternal noncompliance to prenatal care, which can result in delayed treatment or undertreatment. Moreover, it is important to notice the lack of welldocumented treatment of the partners.

The effectiveness of the treatment and the manifestations of CS are dependent on several variables, including the stage of maternal syphilis, the gestational age at the time of the infection, the severity of the fetal infection (the degree of maternal spirochetemia), the adequacy and timing of the maternal treatment, and the immunological response of the fetus. ${ }^{14}$ Firstly, the staging of maternal syphilis is complex to determine; an accurate history, physical examination, epidemiologic features and serologic tests are needed. ${ }^{8}$ In our series, all cases were classified as latent syphilis, but $55.5 \%$ of them were latent syphilis of unknown duration. Secondly, spirochetes can cross the placenta and infect the fetus by the 14th WG approximately, with the risk of fetal infection increasing with gestational age. ${ }^{15}$ The direct damage caused by the spirochetes to both the placental (microvascular proliferation and inflammation) and the umbilical cord may compromise fetal growth. ${ }^{16}$ Thirdly, regarding the treatment, although the majority of pregnancy adverse events are a consequence of undiagnosed, untreated or inadequately treated maternal syphilis, in our study we verified that, among the 8 cases with an adverse outcome ( - Table 2), 5 had been adequately treated and had no other obstetric or maternal comorbidities. Despite the efficacy of penicillin, there are some factors that can justify these outcomes, especially an early stage of maternal syphilis/severity of fetal infection, gestational age at treatment or interval of time without treatment. ${ }^{17}$ Overall, all studies showed a lower prevalence of adverse outcomes between women who had received an intervention in the first or second trimesters of pregnancy..$^{13}$ of those who did not undergo syphilis screening and treatment until the 3rd trimester, Hawkes et $\mathrm{al}^{13}$ observed different outcomes: from $2 \%$ of 
"classical" CS to $68 \%$ of any reported adverse outcome (odds ratio [OR]: 2.24 ; 95\% confidence interval [95\%CI]: $1.28-3.93)$.

With regard to our well-treated CS case, the first penicillin administration was at $30 \mathrm{WG}$, although the exact time of infection was unknown (latent syphilis of unknown duration). On the other hand, regarding the other case of proven $\mathrm{CS}$, the diagnosis was at delivery, and no treatment was instituted.

Inappropriate classification of neonates according to the CDC scenarios, due to erroneous interpretation of maternalneonatal serologic test results or maternal treatment, easily occurs. The lack of well-documented information or incorrect pregnancy follow-up can lead to under-evaluation, undertreatment or even overtreatment in neonates. Of the neonates with "possible CS," two of them presented nonreactive NTTs, and the care provider determined that the mothers' risk of untreated syphilis was low, so no treatment was provided. However, treatment of these neonates with a single IM dose of benzathine penicillin $G$, in order to possibly incubate the syphilis, should be considered. ${ }^{6}$ Before using a single dose of penicillin $\mathrm{G}$, follow-up must be assured; ${ }^{6}$ all of the infants in our study attended all of their consultations. Regarding neonates with "less likely CS," 10 of the 12 cases were not treated, because a close serologic follow-up was provided every 2-3 months for a period of at least 6 months. Finally, with regard to the 2 cases of "unlikely CS," no treatment was required in the case with a nonreactive NTT; however, in the other case, a single IM injection was administered.

Except for the neurosyphilis case (probably due to a faster sequester in the fetal central nervous system before 30 WG), ${ }^{18}$ our study revealed no treatment failures in the infants that were followed-up, demonstrating that the riskbased approach of the CDC recommendations is relevant. In addition, a less aggressive treatment, like a single dose of benzathine penicillin $\mathrm{G}$ or abstention of treatment in "less likely CS" cases, seems to be acceptable in cases of adequate evaluation.

\section{Strengths and Limitations}

The extensive analysis of all cases, crossing information between obstetric and pediatric records, empowers our study, making it unlikely that any case was missed. Since it is a central university hospital, these cases tend to be referred to our center, making our sample more representative of the population from this region of Portugal. Moreover, our data are in agreement with the official rates reported by the ECDC. $^{2}$

The retrospective design of the study is one of its main limitations, making it difficult to study some factors such as behavioral maternal characteristics, data concerning the treatments of some mothers and partners, and the reasons for noncompliance. The small number of detected cases also presents several challenges, in particular if we look at heterogeneity of the data, but it provides a detailed insight into the epidemiology of this rare disease. Lastly, the lack of welldocumented information that must be conveyed between the health centers and hospitals was a further limitation.

\section{Conclusion}

Despite our good results, this study highlights many of the difficulties/concerns encountered in the maternal-neonatal management of syphilis. We highlight the importance of assuring the early detection of the infection, as well as a good compliance to treatment and follow-up, in order to avoid treatment failure. The features that contribute to this failure include the maternal stage of syphilis (early stage), advancing gestational age at treatment, higher NTT titers at treatment and delivery, and short interval from treatment to delivery.

Public health strategies aiming at the early detection of syphilis, at the treatment of infected partners, and at the promotion of access to sexual healthcare services should be reinforced. Better surveillance data are equally essential to understand where the antenatal screening programs are failing.

The proportion of syphilis-positive pregnant women treated ideally by the 24th week of gestation is considered by the ECDC as an important indicator that allows countries to estimate program effectiveness. ${ }^{3}$ Consequently, encouraging all pregnant women to seek care in the first two trimesters of their pregnancies to avoid preventable adverse outcomes should be a priority of the health programs.

\section{References}

1 Gao J, Xu J, Sheng Y, et al. Increasing trend of syphilis and infection resistance: a retrospective study. Int J Infect Dis 2013;17(11): e971-e976

2 European Centre for Disease Prevention and Control (ECDC). Annual epidemiological report 2014 - sexually transmitted infections, including HIV and blood-borne viruses. Stockholm: ECDC; 2015

3 European Centre for Disease Prevention and Control (ECDC). Annual epidemiological report 2014-Congenital Syphilis. Stockholm: ECDC; 2015

4 Gomez GB, Kamb ML, Newman LM, Mark J, Broutet N, Hawkes SJ. Untreated maternal syphilis and adverse outcomes of pregnancy: a systematic review and meta-analysis. Bull World Health Organ 2013;91(03):217-226

5 Le Chevalier de Préville M, Alessandri JL, Traversier N, Cuillier F, Robin S, Ramful D. Evaluation of the management of pregnancies and infants at risk for congenital syphilis: La Réunion, 2008 to 2014. J Perinatol 2017;37(02):116-121

6 Centers for Disease Control and Prevention [Internet]. Sexually transmitted diseases treatment guidelines. 2015 [cited 2016 Nov 12]. Available from: <https://www.cdc.gov/std/tg2015/>

7 Direção-Geral da Saúde. Norma DGS n 037/2011 de 30/09/2011 atualizada a 20/12/2013. Lisboa: DGS; 2013

8 Public Health Agency of Canada [Internet]. Canadian guidelines on sexually transmitted infections. Section 5 - Management and treatment of specific infections: syphilis. 2014 [cited 2016 Nov 12]. Available from: <http://www.phac-aspc.gc.ca/std-mts/stiits/cgsti-ldcits/section-5-10-eng.php >

9 Braccio S, Sharland M, Ladhani SN. Prevention and treatment of mother-to-child transmission of syphilis. Curr Opin Infect Dis 2016;29(03):268-274

10 Chen ZQ Zhang GC, Gong XD, et al. Syphilis in China: results of a national surveillance programme. Lancet 2007;369(9556):132-138 
11 Finelli L, Berman SM, Koumans EH, Levine WC. Congenital syphilis. Bull World Health Organ 1998;76(Suppl 2):126-128

12 Kiss H, Widhalm A, Geusau A, Husslein P. Universal antenatal screening for syphilis: is it still justified economically? A 10-year retrospective analysis. Eur J Obstet Gynecol Reprod Biol 2004; 112(01):24-28

13 Hawkes SJ, Gomez GB, Broutet N. Early antenatal care: does it make a difference to outcomes of pregnancy associated with syphilis? A systematic review and meta-analysis. PLoS One 2013;8(02):e56713

14 Saloojee H, Velaphi S, Goga Y, Afadapa N, Steen R, Lincetto O. The prevention and management of congenital syphilis: an overview and recommendations. Bull World Health Organ 2004;82(06): 424-430

15 Goldenberg RL, Thompson C. The infectious origins of stillbirth. Am J Obstet Gynecol 2003;189(03):861-873

16 Rawstron SA, Hawkes SJ. Treponema pallidum (Syphilis). In: Long S, Prober C, Pickering L, editors. Principles and practice of pediatric infectious diseases. New York: Elsevier; 2011. p. 941-947

17 Sheffield JS, Sánchez PJ, Morris G, et al. Congenital syphilis after maternal treatment for syphilis during pregnancy. Am J Obstet Gynecol 2002;186(03):569-573

18 Silva S, Henriques R, Gomes JP, Borrego MJ, Afonso E. Could we miss congenital neurosyphilis? Lancet Infect Dis 2012;12(10):816 